\title{
VII: WRITING AND LIFE: FACT AND FAIRY TALE
}

For realist Georgian writers of the generation of the 1860s, the question, "What shall I write?" seemed almost as important and consequential a question as the more general question defining the intelligentsia in this period: "What is to be done?" The generation-defining imperative of the aesthetic of "realism," combined with the social imperative to engage with the changing "life" of these new times, left Georgian writers with many practical questions about what to write about. As in Russia (Paperno 1988,8 ) the question, "What was realism?" - the question of the relation between literature and reality, and the function of literature in real life, meant that a large part of this writing would involve writing about writing, or literary criticism (kritika [Paperno 1988, 10-12]). As we will see in this chapter, writing about writing (kritika) also necessarily involved writing about what did, and did not, constitute "reality," or as it was called in shorthand, "life." While it was clear that the current material conditions of the "life" of the people formed the nucleus of the "real," it was not immediately clear what to do with the harmful customs and especially superstitious beliefs of the people in fantastic creatures called chinkas and kajis: did these represent the "traces" of a past life to be passed over in silence or expunged, or did these beliefs, too, represent part of the present ethnographic "life" of the people to be described alongside their material conditions? As I will show in this chapter, paradoxically, the changing treatment of fantastic creatures like chinkas [ch'ink'a] and kajis [kaji] provide a powerful bellwether of changes in the way the intelligentsia viewed the defining object of realism, the "life" of the peasantry, from a largely materialistic rationalizing naturalism in the 1860s (which preferred to ignore or expunge these beliefs) to the explicitly "ethnographic" reading of realism of the 1880s (which tended to treat all customs and superstitions as being equally worthy of description as part of the "life" of the peasants). Intelligentsia quandaries about the definition of realism, then, can be illuminated best by looking at how elements of the folk fantastic fared under changing versions of this aesthetic and epistemic program. Throughout the period, the realism of the intelligentsia is haunted by peasant narratives 
of the fantastic, which initially represent the absolute excluded other of realism, and yet finally are included within its purview.

Our hero, Bavreli, is a typical member of this generation in that he is extremely self-conscious as writer, unable to begin writing without writing about writing. Even at the very moment of the end of the war, Bavreli is not as caught up in the happiness and celebration of the armistice as his anxieties about how to write about it:

From Ardahan (Droeba Correspondence)

- Hurray! Armistice, Hurray! - With this cry one of my comrades, with a bursting heart, came dashing in to me, when I was sitting and thinking about what a newspaper editor would like and what would please a reader... When an inexperienced man like myself takes up a pen and wants to write something, he does not know what to write about. He thinks anxiously: should he write about private [kerjo] life, or about public [sazogado] life? ... If I say something about public [sazogado] life, we ought to know its parts; for this knowledge a man must have eyeglasses, that he can discern these well. Unfortunately I do not have those eye-glasses. ${ }^{1}$

Because Bavreli is anxious and uncertain about what constitutes "public" writing (defined not by address but by topics of general concern), Bavreli begins with the trivial details of his own situated position, his own "private" experience. He describes the recent spring weather in Ardahan, which has been bad, rainy, before that, unpredictable, now cold, now hot. He turns to the sad conditions of the local houses in which they stay, the way they leak so much "that when we sleep, you would think we were lying on the shores of a lake or the banks of a river somewhere, and as we toss and turn, we have to be careful that we don't fall into the lake. ... Now, thank God and Praise Allah, we are saved ... !"2

Having illustrated his private suffering, the "public" question again arises: the announcement of the armistice. Bavreli is skeptical as to whether the announced armistice is real or just a rumor. One day, an officer comes to him and asks him if the war is truly over, and Bavreli convinces him that he may have dreamed it. But it was not a dream; 
finally, the news arrives at the front in Ardahan via telegram. Amid the general explosion of celebration, Bavreli defines himself as a writer precisely by sitting to the side and writing, while everyone else celebrates:

Here today we received a telegram! A sweet voice, a pleasant voice, a voice of peace and armistice! Officers enraptured with this voice go from street to street with music and and are joyful. Shouts of 'hurray' and the pop of champagne bottles cause the very angels in the heavens to tremble...

While I was writing this, another acquaintance came in to see me-a man of an extremely joking and mirthful character. He was a Georgian.

-What are you writing? He asked me.

-What I see around me today — about the armistice.

- So, are you happy?

-Of course! Don't be silly! The whole world is happy and I am not?

$-\ldots \ldots .^{3}$

We will never know what his witty comrade told him, because it bears the marks of the censors. Censors, in this period, made their presence visible, presumably because they acted on the manuscript that was already laid out to be printed, so the effaced text in the form of a series of dots $(\ldots \ldots \ldots)$ reminds the reader of the presence of an absence, and also the presence of state supervision. At the same time, in this scene we see another emergent typifying feature of the writer, the almost self-conscious asceticism, of sitting apart from life in order to write about it, that would later become one stereotype about the intelligentsia, the idea (expressed, of course, in the absolutely paradigmatic context for such an idea, by the feuilletonist Sano in a feuilleton about the intelligentsia) that "the intelligentsia ... must withdraw itself from life" as well as from the social circles of nobility, of the priesthood, or the bureaucracy. ${ }^{4}$

If self-consciousness, metawareness of writing as a socially meaningful, constitutive act defines the new self-segregating class of "writers," then kritika, self-conscious acts of writing about writing (usually taking the form of a feuilleton), would eventually define these writers as intel- 
ligentsia. By the late 1880s, Ilia Chavchavadze would refer the absence of kritika in Georgia not, as some proposed, to the absence of writing worthy of kritika, that is, literatura (Chavchavadze 1977[1887], 132), but to the weakness of the "so-called intelligentsia" and specifically, to their weakly developed sense of reflexivity ("the faculty of talking about themselves, looking at themselves" [unari tvitmsjelobisa, tvitmxedvelobisa]) (Chavchavadze 1977 [1887], 135). Thus, it was not merely the act of writing that constituted oneself as a writer/member of the intelligentsia, nor the act of kritika, writing about writing, that constitutes an intelligentsia, but the reflexivity, the capacity for self-awareness and self-criticism, implied by that act (Paperno 1988, 10-12).

Kritika, writing about writing, especially in the genre of the feuilleton, is the most explicit form of the reflexive intertextuality that constitutes the emergent intelligentsia, but every individual intelligentsia text also constitutes itself reflexively, in part by addressing itself to literary forebears by strategies of intertextuality. Chavchavadze's travel letters made the densely populated literary landscape of the Dariel crossing into a new point of departure for Georgian literary appropriations of their landscape. This particular reading of the landscape based on allegorical personifications of mountains and especially rivers became almost an obligatory motif so that other writers, even if writing about other regions, still felt the need to pay homage to Mount Kazbek and the Terek (map 2). For example, the mountaineer poet Vazha Pshavela (1861-1915) would obliquely cite the opposition between the Terek and Mount Kazbek [Mqinvari] in Letters of a Traveler as his point of departure for an ethnographic dialogue with a Xevsur mountaineer named Torghva: "Many have said something about Mqinvari and the Terek; I also must begin my letter from this, yes, I must, but how? What in the world has been left unsaid?" (Vazha Pshavela 1961 [1892], 127) So too, Bavreli, writing about a completely different part of Georgia, with completely different rivers, still feels the need to locate himself and the rivers of this new landscape of Ottoman Georgia with respect to the "already spoken about" Terek River, as we will see in the next section. 


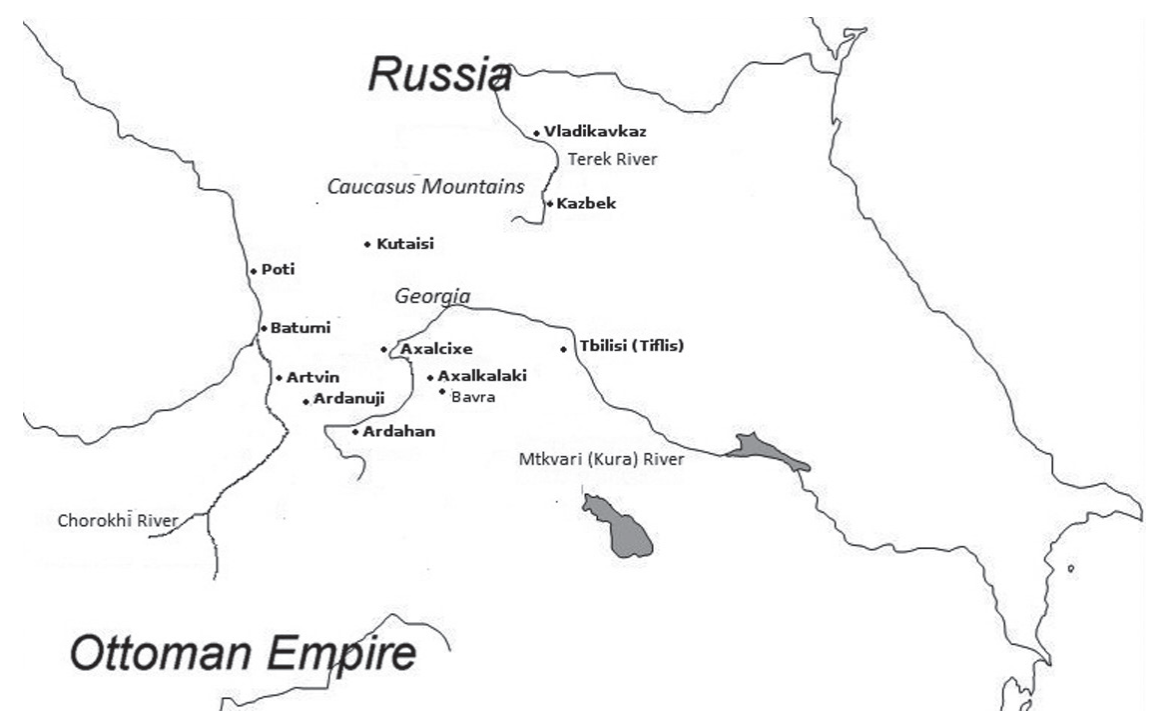

Map 2: Rivers and cities mentioned in the text.

Chavchavadze's travels are along the Terek River which flows from Georgia into Russia (top center), while Bavreli's travels are in the areas between the Chorokhi and Mtkvari rivers in the southwest area of the map.

"In the Land Described by Rustaveli": Realism in a Land of the Fantastic While the self-assured young writer-aristocrat Ilia Chavchavadze found in the Dariel Gorge a literary terrain "already written about," densely populated with the voices of other writers, for his Letters of a Traveler, the socially marginal writer S. Bavreli is a self-conscious, lonely literary traveler, finding in Ottoman Georgia a silent, deserted literary landscape "not yet written about." In order to populate this lonely literary landscape with voices, in his early literary adventure "A Journey by Boat on the Choroxi" (published in Chavchavadze's own literary journal Iveria in 1878), Bavreli echoes Chavchavadze by using an animated, expressive landscape to create intertexts with literary forebears:

Some sort of mournful expression lay on nature and 
brings sorrow to men, here amid high bullet-coloured cliffs the Choroxi, blue like lapis lazuli, leaps quickly and makes a noise like some sort of strange complaint-it is in a hurry to go far away and you would think it is saying 'farewell!' to the cliffs. The fortress and the cliffs echo this noise. I became lost in thought and a daydream took me so that I thought myself in the land described by Rustaveli. But nevertheless the strange voice of the Choroxi drew me. I wanted to understand what it was saying to me, but I could understand nothing, it had become so foreign/strange [gaucxoebula], that its language too now is no longer understandable to us. ${ }^{5}$

Bavreli sees in the strange, almost fabulous landscape, of the Choroxi River the "land described by Rustaveli." Citing Shota Rustaveli's twelfthcentury poem, the Vepxistqaosani (The Knight in the Panther's Skin), a poem that takes place in fantastic lands of the Orient but which was believed to be a covert representation of Georgia itself, allows Bavreli to capture the uncanny sense of familiarity crossed with strangeness of the Ottoman Georgian landscape. But as a literary device, to invoke Rustaveli, the apical ancestor of all Georgian writers and the prototypical object of kritika, was to locate a writer's work within an august lineage. If the genius Rustaveli was a "mirror of his people," as all writers sought to be, for Bavreli, he was also something of a fun house mirror in which the familiar was made strange.

The other literary reference here is of course Chavchavadze's own Letters of a Traveler. Like the semifabulous landscape of Ottoman Georgia, the babble of the Choroxi River is the voice of a Georgia that has become strange, unintelligible, but it also reminds us of the theriomorphic roar of the Terek in Letters of a Traveler. Just as Chavchavadze, in his struggles to understand the complaint of the Terek, eventually turns the theriomorphic roar of the Terek River into an intelligible human voice, finally incarnated in the Terek-drinker Lelt Ghunia, so Bavreli sees the Choroxi, a river which speaks in a strange, garbled voice and appears to be saying farewell to its familiar cliffs and hurrying far away like the people of Ottoman Georgia itself.

The "strange voice" of the Choroxi allows Bavreli not only a point of departure for writing, but also, to define his role as writer as a kind 
of service. Figuring his role as a writer as a translator, a mediator, he wonders how he can translate the estranged and strange voice of the Ottoman Georgia (figured by the Choroxi), if he cannot even understand the strange voice of the Mtkvari River (a river which flows through Georgia, which Bavreli uses here as elsewhere as a figure for Georgia and its people) (map 2). He compares his mediating role in concrete terms as a translator translating between a child who has forgotten Georgian during a long stay in Russia and his mother:

In this case, I and the Choroxi were in the same situation, as a youth returning from Russia to his mother after a long absence. I, your slave and servant, am a witness of this incident. One beautiful day, which are common in Kartli, I was rolling towards Imereti on the railroad. On the train I met a youth, who having returned from Russia was going home; I gathered that he was happy to be going home. Without blushing he told me, "I have forgotten Georgian, I don't know how I can talk to my mother!" He asked me for help in this difficult situation. I helped him. The mother, broken-hearted from happiness threw her arms around the neck of her child and the child too around his mother, but the problem was that could not tell each other their feelings. Then I took it upon myself to play the mother's part, sometimes the part of the child.... But even so I couldn't understand anything the Choroxi was saying, but what would I understand from the Choroxi, when I can't even understand anything the Mtkvari has to say? ... ${ }^{6}$

For a writer as obsessed with the act of writing as Bavreli, even something as prosaic as the technology of writing is worthy of comment. As a writer, desirous of describing this fantastic scenery of the Choroxi gorge, Bavreli segregates himself from the other passengers and the picturesque scene he is to describe, seating himself in the corner of the boat beside the Ottoman navigator and takes out his new fangled "chemical" pen.

I took paper out of my travel chakmaji and a newly- 
invented chemical pen. I had to describe the Choroxi. As I was getting ready and writing about the Choroxi, my Ottoman marveled.

-You are writing in Georgian [gurji-ja], uncle? Our Mullahs, even our lords cannot write with metal and water, how in the world can you write! ...?

Bavreli laboriously attempts to explain the technology that produces this wondrous method of writing without quills and ink, but "with metal and water," using Ottoman vocabulary. From the technological wonder of the European pen used to write Georgian, they move to the exoticism of a book written in Georgian using Tatar letters:

- This is a pen made in such a way, that there is boia (c'amali [medicine; dye]) inside, which makes writing with water possible, I explained to him. Where are you from, brother?

-I am from Maradidi. Our kovi (sopeli [village]) is down below. My bap'oa [sc. grandfather, West Georgian babua] also knew gurjija [Georgian] iazi (ts'era [writing]). Rahmatlogi (cxonebuli [The departed one, sc. the grandfather]) wrote well.

-You don't know? You didn't learn?

-Yes, sir, I know musulmanja [Moslem writing], not gurjija [Georgian writing]. We have katabi [book(s)] of such a kind, that in them Gurjija [Georgian] words are written with Tatar letters. ${ }^{8}$

Technical aspects of writing, from European writing implements to Oriental alphabets, both become objects of wonder when they are used to write Georgian. Bavreli's European chemical pen, which writes Georgian "with metal and water," is paired with the Ottoman's katab, in which Georgian is written with Tatar letters. This familiarity (Georgian language) crossed with a kind of exotic difference ("Muslim" or "Tatar" writing) produces a kind of uncanny effect that parallels the strangeness of the Choroxi River, a quondam Georgian river which babbles in an unfamiliar tongue, the "fabulous speed" of travel on which (G. Qazbegi 1995, 114), parallels the railroad in Imereti. ${ }^{9}$ 
But this is not the only way that Ottoman writing is strange. Bavreli, more or less without comment, establishes that his own version of Lelt Ghunia, Osmana, the riverboat sailor of his narration of travel on the Choroxi, is a typically superstitious Georgian peasant. For Bavreli, writing is a secular act; he positions himself within a universe of writing that at all points belongs to materialism and realism, but for an Ottoman peasant, writing itself belongs to a semisacred sphere, its uses belonging to the order of superstition:

Superstition is widespread here [sc. in the Choroxi river valley]; they believe with conviction in the existence of chinkas and devils in dark and abandoned places. For protection against these [creatures] the Mollahs give them spells - talismans, I have seen inside in the spell there is a small piece of paper, on which are written some words from the Quran. They save this paper in a rag folded into a triangle and they sew it onto the back [sc. of their clothing]. ${ }^{10}$

Writers like Bavreli might use writing to banish creatures of superstition with scientific realism, but the local peasants use writing to banish them with phrases copied from the Quran. The apotropaic devices they use represent an unfamiliar use of writing grounded in an unfamiliar religion, an alterity like that of the Ottoman words that sprinkle the speech of the peasant. However, the creatures that populate their superstitious imagination are familiar Georgian spirits, chinkas [ch'ink'a], which are commonplace in West Georgia (even though Bavreli pretends ignorance of them).

Spying the ruins of a small tower and a wall on the riverbank as they glide along, Bavreli asks about them. He discovers that once there was a bridge there, but that there was a fort there too, and the peasant adds a touch of mystery to these ruins by noting, "Within there are many chinkas":

-What is a chinka?

-A chinka is a devil.

- Then how do you know that there are chinkas there?

-I know, sir, once a certain iolchi (mgzavri [traveler]) 
was coming to his own kovi [village]. It was night. Magier (turme [apparently]) there chinkas met up with him, ast'prula! They apparently brought him into that fortress and they apparently made him dance and were telling him,

This is how they at'ik't'ik'eben [lit. make babble] A traveler as late as you

Apparently, they were having a wedding and they were making a quimass (xavits's [porridge]), they had in the house a great big empty qazana. All of them were sticking their fingers in it and crying out: "Let no one say, that here be his Baraka! . . . The qazana iavash-iavash (nela [slowly]) is filled and they are to throw the traveler himself in too, but had he not called upon Allah, he would have been boiled right then and there, hama allaxi, when they heard it apparently, the chinkas bitun (sul [all]) fled."11

Bavreli is simply eliciting what amounts to Georgian folklore, just as on the plane of form, the unfamiliar terms of the Ottomanized dialect are transcribed and glossed, so too on the plane of genre, this is a typical folktale illustrative of peasant superstitions about chinkas, fantastic creatures who inhabit ruins and torment travelers. Just as the Georgian dialect contains some obvious Tatar words, so Islam enters as a kind of source of apotropaic folk magic, either using writing or invoking the name of Allah. The form and content of the tale are Georgian, not a matter of religious alterity but secular identity of folklore and fairy tales, the chinka is Georgian, Allah is not.

The peasant, who defines a chinka in quasi-religious terms as a species of devil [eshmak'i] might disagree, but in intelligentsia discourse, the preternatural world of folk spirits represents a secular folk discourse of "superstition" belonging neither to the supernatural or religion proper (Orthodox Christianity nor Islam) nor to the natural world defined by secular intelligentsia writers like Bavreli (on superstition as an object of secular discourse see Asad [2003, 35]). Initially diagnosed as part of a set of "harmful customs" to be banished by either religious or secu- 
lar enlighteners, by Bavreli's period these "superstitions" were already being recuperated as a secular component of a shared folklore, a part of the national patrimony (shared, after all, by Christian and Muslim Georgians). Thus, these marginal spirits take on a central role in defining the intelligentsia practice of writing in relation to folk "customs": The spirits of such a discourse, defining a secular zone epistemically opposed both to natural (scientific) and supernatural (religious) domains, represent both the superstitious lack of enlightenment of the peasant to be banished by the intelligentsia, but also a set of national folkloric traditions to be transcribed by them. ${ }^{12}$ Though they do not exist either in supernature or nature, they nevertheless take on a lively existence in the secular sphere of folk or national culture (customs and beliefs).

Bavreli's conversation with the Ottoman boatman about chinkas sits on a watershed between these different approaches to describing peasant "customs" and "superstitions." In the more materialistic and naturalistic realism of the 1860 s-1870s, peasant stories about such spirits are diagnostic of a painful absence of scientific enlightenment and part and parcel with the "harmful and impoverishing customs" which everywhere strangle the "life" of the peasantry. By the 1880s, in the wake of the turn to a self-consciously "ethnographic" reading of realism centering on the mountainous regions of Georgia, the preternatural world of chinkas and kajis has become as topical a theme for Georgian writers as writing about the natural world of the peasants who believe in them, belonging to the secular and national culture of the peasantry. Thus, the mere existence of Bavreli's factual report of a conversation with his Ottoman boatman about chinkas is as much an example of "writing about writing" as their discussion of technologies of writing itself, for simply to report a factual narration about fantastic creatures like chinkas presupposes a specific kind of answer to the question, "What should I write?" and the related questions "What is realism?" and "What is real (life)?" to which I turn next.

\section{Writing and Life: Realism}

Writers like Bavreli accorded a certain urgency to their task, for writing (and writers) responded to the urgency of "life." To write was to write about "life," and to write about life was to write about "the people" (who typically could neither read nor write themselves), and eventually to 
write "for the people" (as part of a growing campaign to spread literacy beginning at that time). Early correspondents of Droeba like Mose (Ingilo) Janashvili saw themselves as living on the precipice between two epochs, an "old life" and a "new life." To build a new life, the writer must be critical with respect to the old life, and literature must assume a practical, utilitarian role with respect to the new one, writing and "theories" must be grounded not in "air" but in "life" (cxovreba): "my desire is that literature must obey life. Every word must be adapted to life; our life and present questions must be researched."13 "Life" is a key word defining the field of intelligentsia activity of all kinds.

What is meant by "life"? The words used in Georgian, typically cxovre$b a, q o p a$, or qopa-cxovreba, have some of the same specific nuances of the Russian word byt in the same period:

Loosely translated, byt encompassed all of the following English terms: 'daily life', 'domesticity', 'lifestyle' or 'way of life'. Prior to the Revolution the term byt had largely ethnographic implications, and was used to describe differences in daily life represented by traditional ethnographic subjects such as Siberian aboriginal groups, as well as traditional European peasant societies. With the Revolution and the problem of constructing a new socialist society the word byt assumed increasing political significance.... (Buchli 1999, 23)

But activism directed at changing "life" does not begin with the Russian Revolution; it is an abiding and defining concern for intelligentsia in Georgia from the period of Emancipation at least. For writers like Ingilo writing in the Emancipation period which coincided with the beginning of Droeba, "life" was the present period that was fettered by the harmful "customs" from the past. By the socialist period, however, "life" had become identified instead with the past in the present. Life, then, was the dead weight of the past which stood opposed to future revolution, the future. As Boym notes, by the late nineteenth century, "life" had come to mean that which was resistant to revolutionary change by the avant-garde, under the influence of symbolists and early revolutionaries in the late nineteenth century who saw byt as "the reign of stagnation and routine, of daily transience without transcendence ..." (Boym 
1994, 30). In an influential series of formulations, Trotsky essentially identified byt as a mixture of the present "given conditions" and the past "customs," but is heavily slanted toward the past.

Daily life [byt], i.e. conditions and customs, are, more than economics, 'evolved behind men's backs,' in the words of Marx. Conscious creativeness in the domain of custom and habit occupies but a negligible place in the history of man. Custom is accumulated from the elemental experience of men; it is transformed in the same elemental way under the pressure of technical progress or the occasional stimulus of revolutionary struggle. But in the main, it reflects more of the past of human society than of its present. (Trotsky 1973, 29)

For Ingilo, too, writing in the 1860s, life is a category defined in terms of the times (droeba): Life is cleft in twain by an epochal divide between the "old, extinguished life" and the "new life." In one sense, life might include the past life and customs (the old life), but in another, life (including what Trotsky would call "given conditions") is identified with the present and directly opposed to customs, the past life. The opposite of life and the present is custom and the past, the duty of writers is to describe life with a view to changing life, in particular by identifying and eliminating bad customs among the people:

The duty of the writers is that they don't put cotton in their ears and close their eyes to everything that is happening in life, good or bad, then they must put their hand to the task and pronounce it in literature, and in this way cut off the roots of the bad customs of the people ...14

For Ingilo, customs are the remnants of the old life that must be destroyed to build the new one. For another writer (Chkotua), customs were similar to Tylorean "survivals"; they are the "result" (shedegi) or "trace" (kvali) of the past conditions of life that are retained in the present life, but no longer make sense in terms of the conditions of present life: 
There is many such a custom [chveuleba] that has remained in the life [cxovreba] of the people, whose original idea and significance we no longer understand, which we consider to be almost laughable or ridiculous. .. . Really, what is 'custom'? Custom is the result of the life [cxovrebis shedegi] of a people or a private individual, it is the trace [k'vali], in which is imprinted the past conditions of life. ${ }^{15}$

However, the collection of such customs could be regarded as having a certain utility. Another author (Antimozi) describing customs among the Mingrelians notes, "It has been said many times, that there are among us such customs, which clearly portray for us the effect of the people of old, who lived among us at different times, on our own people [xalxi]. For this reason we consider it to be very useful to collect the customs, superstitions, and fables [zghap'rebi] of our people: these bring great utility for the writer of the history of our people."16

For writers as different as these, life is a category of the present tense; customs are products, effects, or traces of a past life. The utility of customs is always weighed in terms of the present life: customs are "harmful" if they have negative consequences for contemporary life of the people; they are "useful" if, for example, they help us understand the past life of the people. This has a particular effect on the descriptions of customs of the people, of course, for they are described often because they have crucial moral and material effects. Life was the ultimate ground of reality, and the duty of a realist author was to study life; the duty of a critical realist author was to help remove the old life and bad customs and find a new life.

\section{"Harmful" and "Useful" Customs}

The relation of writing to life was therefore materialistic in its ontology, realistic in its epistemology, and utilitarian in its teleology. This definition of writing in relation to "life" explains the specific epistemic and aesthetic mode that characterized "writing about life": a scientific realism which differs little from that in Russia in the same period, as summed up by Frierson:

The characteristic approach [to the description of the 
life of the peasants] was a commitment to what they understood to be scientific principles: rationalism, empiricism, and objective realism. Their sideward glance was directed at romanticism an as inadequate attitude that failed to penetrate 'reality' and thus did not offer useful guidance on the pressing concerns of transforming Russia ... The structure of their accounts of village life ... bespoke their effort to appear scientific. Each typically opened with a description of the physical setting of the report or sketch, thus establishing the major features of the geographic, climatic, and economic environment. They were striving for what was essentially a positivistic account of peasant society. (Frierson 1993, 27-8)

A typical Georgian example of such correspondence is an early letter to Droeba about the West Georgian region of Racha in 1868 by U. Uximerioneli. He begins by ruminating on the status of Racha as a kind of terra incognita for what he calls "Georgians, that is, readers of Droeba," since, like many of the early correspondences to Droeba in the 1860s, Racha is located in West Georgia, and is thus relatively mysterious and unfamiliar to the largely East Georgian urban readers of Droeba. Thereafter, this correspondence is structured much like an eighteenth-century natural history, making a steady descriptive progression from the material and natural to the moral and human orders, from natural history to civic history. The first letter moves from the geographical location of Racha in the mountains, the geography of Racha itself, its isolation resulting from mountainous location, resulting frequent landslides and resulting poor condition of roads, climate, quality of local mineral water and soils, cereal and wine production, the need for the population to search for work elsewhere half the year because of the shortage of land, the reputation of Rachan craftsmen in the plains of Georgia, and the general demography of Rachan villages. ${ }^{17}$ With the second letter, we have moved to the human order, civic history, with a description of both the physical and moral character of the Rachans, compared to other Georgians, including desirable properties like industriousness, balanced, however, by a lengthy discussion of their proclivity to superstition (to be discussed below), a description of religious festivals, the ethnic makeup of Racha, and the establishment of village courts of justice. Here, the letter trails 
off, unable to finish this discussion, for fear of boring the reader with what is already a long discussion. ${ }^{18}$

In fact, this early correspondence was singled out for praise by the writer signing himself T. Akaki Tsereteli ( $T$ stands for Tavadi "lord"; Tsereteli is a noble), for illustrating a happy exception to the rule in Droeba's correspondence to that point, which was, in Akaki Tsereteli's opinion, confined to long lists of tedious facts about the material situation of the region. First, Tsereteli praises Droeba for being the first newspaper to contain local correspondence at all, but complains at the same breath that the correspondents themselves do not pay attention to the right kinds of details about their regions: "its correspondents do not pay attention to real and necessary matters and write such stories for us, that if we didn't know them we wouldn't be missing anything, and knowing them gains us nothing! . . " ${ }^{19}$ What then, counts as useless knowledge for Tsereteli?

Well, my good man, why do we need to know whether a lot of wine was produced in Imereti this year or not? . . . In Imereti if a lot of wine is produced, they drink a lot, if not, they gulp down water. ... Such correspondences, that is, those that talk pointlessly, it is best that they not be printed in a quality newspaper! ${ }^{20}$

The editors, of course, took major exception to Akaki Tsereteli's lightminded dismissal of "material conditions", for example, of the importance of the wine harvest in Imereti:

It is strange, how the author of the article does not understand this clear truth, that a good wine harvest has a big influence on the public commonwealth, especially among us [Georgians]. It is true, that there are those, who if they have a lot, they 'gulp down' a lot; but the author should have taken into account that majority, who sell extra pitchers [of wine] and exchange them for a couple of pairs of sandals a year. ${ }^{21}$

One can see in the difference between the lord Tsereteli and the editors of Droeba here a pervasive divide on what constituted items worthy 
of narration, Tsereteli preferring less talk about the material conditions of life and more talk about the customs, the editors of Droeba arguing for the importance of material conditions of life for the people. Implied here is also an emergent divide between what the local correspondent wanted to write about their locality, and what the elites in the city (whether the editors or readers like Tsereteli) wanted to know about the life of the peasants.

The question of what was important to write about was directly related to the question about what to do about it. Here, the local correspondents and the editors of Droeba frequently disagreed. One correspondent from Racha, one of many who wrote against the inordinate expenses of funerals, took the materialist and economic view (so disliked by Tsereteli) to an extreme, providing an exact (and extremely detailed) accounting of the crippling expenses that funerals represent for peasants, eventually arriving at the princely sum of 208 rubles and 80 kopeks. ${ }^{22}$ This correspondent not only criticizes these customs for being harmful, impoverishing, and pointless, but also because they are, in his opinion, not Orthodox, but survivals from "our ancestors, who apparently at one time were followers of another religion" that have remained unchanged until today. The goal of this local correspondent in tabulating such a complete list of charges (down to the last kopek), like so many others, is to enlist the aid of external agencies in eliminating these harmful and impoverishing customs, in this case advocating the government use force to eliminate them (since the people are opposed to abandoning the customs of their ancestors). He asks, "What opposition could there be for local government to make the people abandon such customs by force; this will please both the people themselves and the people of other estates too. They know, don't they, that this custom is harmful and impoverishing for them?!" Here the editors, in a footnote, take a major exception to the elimination of customs by force, advocating instead that village teachers and priests should attempt to enlighten the peasants.

This letter is a relatively early example of what constitutes an utterly banal form of "local" correspondence, demonstrating how materially and economically crippling such "savage customs" (mxecuri chveuleba) are (with a particular criticism of the depredations of the priests) for nobles and peasants alike. As an editor to Droeba would despair in the following years, letters about "harmful and impoverishing customs" 
such as this form a huge and popular genre among reform-minded local correspondents. In fact, they form the bulk of "local correspondence":

When we look over correspondences printed in local newspapers, we will read 365 times a year at least, if not more, about useless expenses, which the people pay in burying the dead, on New Year's celebrations, on weddings, or other kinds of gatherings. In the opinion of correspondents, these gatherings form the primary cause of the poverty of our people and if priests by preaching and teachers by teaching can help wipe out these harmful customs, then the welfare of the people will be greatly promoted. ${ }^{23}$

If Tsereteli and the editors of Droeba disagreed on the relative importance of describing the moral versus material aspects of custom, the correspondence from the village seemed unanimous in seeing such customs as being materially impoverishing and morally harmful. The customs in question were primarily those related to funerals, including both the crippling material expenses but also the dubious moral practices such as ritual wailing, customs especially characteristic of West Georgia (Imereti, including Racha, Mingrelia, Svaneti), which was becoming clearly identified as a veritable hotbed of backwardness. ${ }^{24}$ The litany of local correspondence was in favor of eradicating this or that harmful and impoverishing custom. In response, the editors of Droeba often used their editorial page to point out that "custom" was not always "harmful and impoverishing."

Facts versus Fables: Ghost Stories As Superstition

In his criticism of the correspondence to Droeba, Akaki Tsereteli singles out the Rachan correspondent Uximerioneli above as an example of what a newspaper like Droeba should write about, specifically singling out his description of "the customs of the people." The customs that interest, or rather distress, Uximerioneli are, indeed, not materially impoverishing ones that distress other correspondents, but primarily moral ones: superstitions. According to Uximerioneli, the primary moral problem of the Rachans is that they are a very superstitious people. As a scientifi- 
cally minded person, he is distressed by their superstitious tendencies to attribute preternatural agencies to natural phenomena. Before even illustrating this superstitious tendency, Uximerioneli apologizes to his scientifically and serious-minded readership that he is about to relay the sort of story that the peasant regards as a factual "narration" (naambobi) about the forest inhabitants, but the reader will surely recognize as a "fable" or "fairy tale" (zghap'ari), something which, if they have heard such a story before, they can pass over unread:

Among the Rachans superstition is very widespread. Apparently different phenomena of nature have frightened the people (xalxi) and it has created ideas about the existence of some sort of evil men of the forest, which they call kajis, chinkas and women with tails [i.e. witches]. I want to relate here one story [naambobi, a narration] about these inhabitants of the forest, and I ask the reader, if he has ever heard fables [zghap'rebi] like this one, that he omit this section and not trouble himself with reading it. ${ }^{25}$

However much Tsereteli apparently enjoyed his account, Uximerioneli (like most correspondents of his time) is a reluctant, even apologetic, narrator of ghost stories and fairy tales (zghap'rebi). With his reluctance and apologetics for even so much as a retelling of this dubious material, the author establishes a crucial distance between a scientific epistemic stance shared by the author and the reader, and that of the superstitious peasants, who present fables (zghap'rebi) as narrations of fact (naambobi).

Like any good ghost story, the story begins with a frame narrative of travelers arriving at a local inn (dukan) on a dark and stormy night. Because of the lack of beds and the noise coming from a stream nearby, they spend a sleepless night in the inn. At dawn, the owner of their horses, who had been delayed and came after them, finally appears at the door, and from him we get our first ghost story:

He knocked, we opened the doors for him, we looked at him: this man is very pale in color, and he is holding a big rifle in his hands. As soon as he came in, he called out: 'In 
my entire life I have never experienced such difficulties as these, what devil made a fool of me, that I spent the night in such a cursed place. The whole road, I swear, I didn't take a breath, the whole time I was looking this way and that and I had the rifle at the ready in my hands; and God protected me, if he hadn't then, as you also well know, these forests and cliffs are completely full of devils and tempters.'

'There,' he continued, 'where there is a lovely meadow, there I encountered a lovely woman. I called out to her: "Who are you, tell me, a devil [kaji] or a man [k'aci]?" She mumbled something incomprehensible and didn't reply to me and went along with me for about 40 strides and then, when I looked she was no longer accompanying me, I crossed myself and called out "Fie on the Devil, Fie on the Tempter!" I made sure the tempter had vanished, so too did your enemy vanish!'26

Such is the first Rachan ghost story, told with conviction of truth and faithfully transcribed. Our main narrator now breaks frame to insert a parenthetical comment: 'this 'tempter,' in our opinion, was a young Mingrelian shepherd, whom we ourselves had met along the road and who did not understand Georgian." Mingrelian boys who do not speak Georgian, in the dark, might well be mistaken for feminine demons by a frightened and superstitious peasant. But this naturalizing diagnosis of superstitious mistaken identity remains as yet unspoken in the dukan, but is only shared as an aside with the other "Georgians, that is, readers of Droeba." Speaking out loud, another traveler instead identifies this tempter as a dangerous form of witch who might have struck him mute or made him lame.

But as it happens, this was not the only frightening forest creature our traveler encountered that night; he continues, "At this accursed place at the same time, a kaji came twice with a roar and a scream like wildfire down from the cliffs and made a crashing noise flow through the trees in the forest. At that moment I aimed my rifle, fired it, and the kaji fell over into the water with one voice and one scream." This second story causes those present to cross themselves, and some of them have their hair standing on end and elicits a general diagnosis in the dukan: 
that Racha, of all places in Georgia, is particularly densely populated by witches and kajis:

'No, there are kajis and witches in our land,' the same one began, 'so many as are found nowhere else. There where there are caves in the cliff, from there a kaji threw a rock at me and nearly broke my head open; as I passed by again a little later and under the clear, star-studded sky a devil threw water and snow at me from the cliff, may God curse his mentioner.'

'Really, I swear,' added another traveler, 'The kajis know how to do marvels; if it is good weather, they throw snow at you and if it is bad weather they pelt you with dry earth and rocks. ${ }^{27}$

Here the narrator can no longer restrain himself, and breaks into their conversation in the dukan to retell their stories to them in terms of what really happened in scientific terms of nature and not superstitious fable: the kaji who came down from the cliff with a roar and a scream through the woods was an avalanche, and "as far as the throwing of rocks is concerned, rocks fall from cliffs really often and we also have been hit in the back, but we very much doubt, that kajis and witches threw them! ..."

It is as if he had not spoken at all. His attempts to naturalize the preternatural world instead elicit more of what he calls zghap'rebi (fairy tales) and arak'ebi (fables) that take us deeper into the peasant cosmology of preternatural beings, moving from allegedly factual narrations of kajis in Racha to similar narrations of chinkas in neighboring Imereti. Significantly, when repeating the man's factual narration in indirect discourse, the writer replaces the particle rom ("that"), which introduces a noncommittal evidential value, with vitom (which we have already seen is used for narrating one's own dreams and narrations presented as factual by others (naambobi) which the reteller judges to be dubious or false like zghap'rebi):

'A kaji is a kaji, isn't it? I am not one who has seen one,' began an Imeretian traveler, who, like an attorney, 
sometimes pointed his finger at us, sometimes pointed it upwards and waved it this way and that, 'but a man among us had a chinka, and this I know for a fact.' He told his tale [zghap'ari], which we have heard many times in Imereti: allegedly [vitomc] a man had caught a chinka in the forest and he clipped its nails, and he made it help him as a servant at home. On one Sunday, when the owner of the house had gone to pray, this chinka tricked his son into telling him where the clipped nails of the chinka were hidden. The chinka took out his nails and he pasted them back on his own hands and feet and supposedly this made his strength come back and he stole off. The youth, on the other hand, was supposedly thrown into boiling water by the chinka. 'So I heard, I wasn't there to witness it myself.' Our traveler finished his narration [naambobi]. Earlier he had been trying to convince us that supposedly he had seen a chinka himself. In general they are all like this, they tell such fables [arak'ebi] and whoever you ask, no one can tell you that they themselves have actually seen witches and kajis. Such fairy tales [zghap'rebi] and superstition are very wide-spread in all of Racha and Imereti, too. ${ }^{28}$

Uximerioneli is seemingly embarrassed at even retelling these fairy tales, and it is noteworthy that this narration is virtually unique in the period; I have found no other transcriptions of fairy tales until the ethnographic boom of the 1880s. So why does he retell ghost stories and fables at all? On the one hand, this retelling establishes the epistemic solidarity of the readers of Droeba (who recognize these stories as fairy tales, even if they enjoy them) as opposed to the superstitious folk (who cannot recognize the retelling of their own fairy tales in the naturalistic terms of science). Two orders of narrators are created in correspondence (correspondents and peasants), and two orders of narrative (written and oral, factual narration and fairy tale), each belonging to two absolutely opposed epistemes (science and superstition; naturalist and animist); each populated by its own typical narrative agencies (avalanches and kajis, respectively); recreating the opposition between "society" ("Georgians, that is, readers of Droeba," those who write cor- 
respondence and do not believe in kajis) and "the people" (those who they write correspondence about, who tell stories about kajis). At the same time, by narrating his own failed attempts to explain the stories in naturalist terms, in terms of Mingrelian shepherds, avalanches and not kajis, first as an aside to readers of Droeba, second, to the peasants themselves enlighten them, a foray of the discourse of Droeba into the West Georgian village dukan, he shows that there can be no dialogue and no reciprocity of perspectives between these two spheres of circulation. The naturalistic discourse of the correspondent to Droeba is passed over in silence by the peasants in the West Georgian dukan, just as Uximerioneli suggests his retelling of their fairy tales can be passed over unread by the reader of Droeba.

\section{Fables As Cultural Facts: Ghostly Ethnographies}

Just two years after our Rachan correspondent made embarrassed excuses for retelling the zghap'rebi and arak'ebi of the peasants in the Dukan, Umikashvili's call for the collection of folklore in villages in 1871 called upon collectors to include those, along with a wide range of other "folk" genres (saxalxo) which are also "national" (saero) genres, "what the peasant men of the village sings and says." These included (1) poems (leksebi), either sung during work or play; (2) fairy tales (zghap'rebi), stories (ambebi) of heroes, fables (arak'ebi); (3) proverbs (andazebi); (4) poems (shairebi); (5) blessings for sickness (shelocva ram avadmqopebisa); (5) prayer either from the period of idolatry (k'erp'oba) or Christianity, but the latter only if the people have remade in a specific way (taviseburat gadauk'etebia); and (7) riddles (gamocanebi). One notes in passing that intelligentsia writing about the secular sphere of folk customs is extremely carefully segregated from the sphere of "religion" (a category that includes Christianity and Islam, but not, for example, paganism or idolatry). Thus, while all customs left over from the time of idolatry belong to the "folk," Christian prayers are "folk" only when they have been remade in a non-Orthodox "pagan" fashion; Orthodoxy itself is not part of the sphere of the "folk," nor is it (unlike idolatry!) within the purview of secular "custom" or "superstition," that is, a secular topic that the secular intelligentsia can write about. Accordingly, by the late 1870s, the situation had changed enough that Bavreli felt that precisely such stories about chinkas from his boatman were interesting and worth re- 
cording, dutifully transcribed with appropriate attention to their form, just as Umikashvili in 1871 suggested in his call for folklore by correspondence.

This particular secular sphere of "customs and superstitions" is a privileged sphere for intelligentsia writing about the folk. Importantly, such beliefs did not belong to the sphere of religion but did belong to the sphere of national culture (after all, chinkas are found both among Orthodox and Muslim Georgian peasants). Just as their role as enlighteners required them to teach the peasants the benefits of scientific naturalism, their role as cultural workers required them to document the mistaken superstitious beliefs of the peasantry, which nevertheless were an important aspect of national culture. Even in the nineteenth century, then, intelligentsia found in folklore and folk superstition a domain in which they could both define themselves in opposition to the unenlightened folk (who sought supernatural explanation where natural explanation was required) and also unify themselves to those same folk with a secular narrative sustained by an emergent concept of a "national culture," in which folklore and mythology would play an important role.

In the earlier period of realism of the 1860s (typified by Uximerioneli's correspondence) which privileged discussion of "life" over "customs," stories about kajis and chinkas are reported with apologies and reluctance, primarily to show that the people are superstitious and unaware of natural causation, embedded in a larger naturalistic narrative that attended to, for example, the material plight of the people of Racha (lack of land that causes them to engage in guest work elsewhere). By the 1880 s, there is something of a sea change in favor of ethnographic realism, and the pages of Droeba, and later, Iveria, are full of ethnographic, folkloric, and other accounts of the "moral" life of the people. In 1888, a description of folk beliefs in West Georgia about kajis, for example, could be taken up instead as an unapologetic study of folk beliefs, without any concomitant description of their material conditions of "life." The basic epistemic divide between enlightened society and the people is not challenged by this relativistic description of custom and belief, rather, it could be argued that it is even firmer. In the spirit of "liberal" models of dialogue discussed above, Uximerioneli at least attempted to persuade the peasants he wrote about that there were other forms of explanation; he not only wrote about their superstition, he talked to 
them and argued with them. On the pages of Iveria, firmly within the universe of "conservative dialogues" with the peasants, the peasants are much more hermetically sealed in their epistemic universe, but the writers are much more willing to show the inner logic of that universe: now, ideas about kajis are interesting in themselves, not merely as a sign of the superstitiousness of the people.

With folkloric and ethnographic reportage characteristic of the 1880s, superstition is transformed as a negative property of the "material order" (ignorance of real material causes) into a positive property of the "moral order" (folklore), revelatory of Georgianness. At the same time that the fantastic kaji is redeemed as a form of folklore, it nevertheless remains constitutive of the epistemic horizons of folk discourse, the written about, and not educated society/intelligentsia discourse (their writers), ultimately to be overcome. The fantastic and the folk are mutually constituting: realism can report the fantastic, but not participate.

With this redirection of realism, we can see the transformation of mistaken, fantastic, folk beliefs into historical facts about the folk, as Figal (1999, 134, see also Foster 2009, chapter 4) notes in a parallel case with the codevelopment of the folkloric and the fantastic in Japan, "[A]lthough the content of tales and legends were not historical facts .... the very telling of and belief in such stories among people were historical facts that could and should be dealt with in a cultural history ..." That is, the discourse of the folk and the discourse of the fantastic could be mutually constituting (under the secularizing rubric of "custom, belief" of the folk other) and opposed (under the rubric of folk superstition, backwardness, or a strictly materialist discussion or a strictly realist one).

Thus, a description of folk beliefs about kajis in Imereti in Iveria in the 1880s will be a very different thing from what we have seen from Droeba in the 1860s. From the very start, we are brought into the universe of discourse of the zghap'ari (fairy tale), taken on its own epistemic terms as naambobi (factual narration). First, we are given a description of the Imeretian kaji:

A kaji, in the viewpoint of the folk, is similar to a man and with a big enormous body, ugly to look at and it expresses horror itself at its own appearance, it has a body covered in hair, and, of course, does not wear clothing; 
on its chest it has spines, which, when it becomes angry, it releases. ${ }^{29}$

The kaji is distinguished from the humans it otherwise resembles by physical monstrosity and nudity, but it is distinguished from other devilish creatures, such as the chinka, partially by time and place of operations: the chinka is defined primarily in temporal terms, the kaji primarily in spatial terms:

The kaji does not have a time of coming and going, like for example, the chinka, and it is always here. The kaji is very distinct from the chinka. The chinka is more like a domestic/interior [shinauri] creature and does harm to domestic animals, objects and furniture, the kaji, however, is wild/exterior [gareuli], it does not come near the house and does not harm anything domestic [shinauri]; it harms the man himself, if a kaji runs into a man on the road, it begins to wrestle with him, if it defeats him, it doesn't kill him, but it really 'daaquebs' (daamt'revs ['thrashes']) him. ${ }^{30}$

In this clear, almost structuralist analysis, the chinka and the kaji are almost perfect opposites, each haunting half the key cultural division between the household/domestic/tame/inside (shinauri) and the wild/exterior spaces (gareuli): the kaji haunts the latter and avoids the haunts of the chinka. The appearance of the chinka in domestic spaces is according to time of day, while the kaji is restricted by time but more particularly a creature located in spatial terms and subdivided according to more specific details of its hauntings:

The folk do not really know where the chinka lives, but the kaji, in the opinion of the folk, lives in big cliffs, caves and desolate places, in creeks and in water. According to the place of habitation, the kaji is of two types: one is of water [a dweller in water], the second, of dry land [a dweller on dry land]. Since by its own activity the kaji resembles a man a great deal, for this reason the folk have called the kaji by the different names 'water man' 
and 'forest man'. Kajis of the two breeds walk about on the earth from twilight to the cock's crow; afterwards they hide themselves in their own places. At night they wander about here and there and avoid humans. If a kaji of the dry land runs into a man, then he begins to fight with him and there are many examples of this among the people; the water kaji does not fight much with men and I couldn't find a single example among the people of a water kaji fighting with a man. ${ }^{31}$

Kajis obey specific rules; for example, when one sees a kaji, one should greet it in the normal Georgian fashion "gamarjoba!" ("Victory!") before the kaji has a chance to do so. If one does so, and if the kaji forgets itself and gives the normal reply greeting "gagimarjos!" ("Victory to you!"), then, as the greeting itself implies, you will win the following fight. They are also afraid of the sound of bells and particularly the sound of iron objects. The author gives several illustrative stories of fights with kajis as reported by the people. If one wins such a fight, then it is possible, as with a chinka, to take the creature home, but this is pointless, for unlike a chinka, the kaji, a wild spirit, cannot be domesticated:

Even though a kaji can be caught, still it cannot domesticated, that is, it cannot be kept it at home by cutting its hair and toenails, as for example with a chinka. The folk do not remember such an example of anyone managing to domesticate a kaji. Whoever catches a kaji, it is said, that kajis will never again come near anyone of their surname. $^{32}$

Other than tricking them with greetings or beating them in a fight, kajis are, like other Georgians, fond of wine, but kajis cannot hold their wine, unlike humans:

Aside from chance encounters, some kajis actually chase after humans. In such circumstances, if it has caught up with you, you must pour wine for the kaji, and, because it likes wine a lot and wine has a greater effect on it, it will not refuse and it will soon become drunk. The moment it gets drunk it falls asleep. 
Then a man can easily save himself. ${ }^{33}$

While the chinka is a domestic creature that can be domesticated and turned into a servant by physically removing some of its "wilder" physical features (cutting its nails and/or hair), the kaji cannot be so domesticated. However, as with an interaction with a stranger, who represents a potential enemy or a potential guest, the kaji's malevolence can be domesticated by either physical prowess (as an enemy) or by sociable means, by greetings, and by traditional Georgian forms of hospitality (offering them wine). The chinka is the fantastic image of serfdom, of domestic servants, animals, or children turned into wild malevolent beings, who can in turn be enslaved; the kaji is the fantastic image of the stranger, a perfect stranger from whom nothing can be gained and with whom no permanent relationship other than avoidance can be formed.

Even though, in many ways, kajis are the opposites of normal humans (kajis are often marked by doing things backward and speaking backward in other folkloric accounts), there are uncanny similarities between kajis and normal people, as this writer notes. In fact, kajis do not represent the opposite of society (they do not lack a social order), but an antisociety; they themselves have a society in the desolate wastes (ruins, caves, forests) which at all points mimics that of humans. In one story, for example, the hero kills two kajis who are brothers, and later witnesses their funeral, which involves the same kinds of ritual wailing characteristic of Imeretian peasants. That is, the society of "men of the forest" is still very much a society. It is antisociety, but not an absence of society. The author concludes,

From this example, by the way, it also appears that the kaji by his actions and manner of living very much resembles a man. The kaji is tall in body, portly and has small arms, [but] like a man he has as customs: lamenting the dead. So consider the following, that kajis even have a political order and life, too. They have the very same sort of elders as in the society of men; they have one main elder, whom all kajis pay respect to ... ${ }^{34}$

The kajis have not only become the object of folkloric study but of 
ethnographic study as well, they live in communities just as mysterious to, and yet uncannily similar to, those of the (Western) Georgian peasant, as the (Western) Georgian peasant is mysterious to the (Eastern Georgian) intelligentsia.

\section{The Fantastic As Metaphor for the Real: Peasants As Kajis}

“This 'tempter', in our opinion, was that young Mingrelian shepherd, which we ourselves had met along the road and who did not understand Georgian."35

One could, in fact, study the folkways of the kajis much as one would study the folkways of the peasants who tell stories about kajis. For kajis have customs, political orders, and social life very much like those that the ethnographers at this time are scouring Georgia to document among the peasants. In fact, the custom this author uses to illustrate the parallelism between the customs of kajis and the customs of humans is precisely the custom most often treated as epitomizing the backwardness of West Georgian peasants relative to East Georgian ones: lamenting the dead (t'irili), a harmful moral practice embedded in a series of equally "harmful and impoverishing" material expenditures. Thus, kajis in fact seem to resemble the (West Georgian) peasants who tell stories about them, they are the more uncultured, more natural, and wilder equivalent of those peasants. In the same way that West Georgian peasants tell stories about kajis, writers in Droeba tell stories about West Georgian peasants (who are telling stories about kajis).

The most famous piece of Georgian writing in which kajis figure is Rustaveli's Vepxistqaosani, the twelfth-century poem in which kajis serve as the villains. Like their nineteenth-century versions, kajis are imagined in the Vepxistqaosani not as fantastic (superhuman or subhuman) others, but humans on the same order as the heroes. This Rustavelian figure of the kaji as a nonsupernatural other crops up, once again, in the appropriation of Ottoman Georgians into Georgia. Amid the many attempts to map the fictive space of Rustaveli's poem onto the map of Georgia, it involved an identification of parts of the Ottoman Georgian city of Batumi with the fantastic fortress of the kajis in Rustaveli's twelfth-century poem. Naturally, such identification of 
spaces from the privileged national narrative with recently reconquered territory of Georgia leads to a powerful way of synthesizing these spaces with the national narrative. But of course, such syntheses have other consequences, including the jarring connection for many Georgians of the period of a human form of alterity with a supernatural/superstitious form of alterity.

This invocation of Rustaveli is the device used in one travel account that appeared alongside that of Bavreli in the pages of Droeba of 1879, by A. N_dze. This account chronicles a sea voyage from Poti in Mingrelia south to Batumi, in which the writer realizes two dreams of his, to see the sea and to see "our newly united Georgia as well." ${ }^{36}$ He gives a leisurely description of Poti, which he terminates, because "the Georgian readers of Droeba will not need to be introduced to Poti, for all will know about it." ${ }^{37}$ Finally they depart, having a rough sea voyage to Batumi. Finally, the sea calms and at the same time Batumi comes into view. Quoting from Rustaveli's medieval poem, the Vepxistqaosani, the writer and an acquaintance of his identify Batumi with the semifabulous city Kajetis Cixe (The fortress of the land of kajis), wherein dwell the semifabulous creatures, the kajis, with whom the heroes of the poem must do battle to save the beautiful princess. If this is the land of Kajeti, the writer's friend reasons, then the inhabitants must therefore be kajis themselves:

My interlocutor pointed out some emaciated, pallid young boys and told me:

-Look, those are the inhabitants of the Fortress of Kajeti, whom Rustaveli in his undying poem calls Kajis!

I couldn't make out the devilish (kajuri) in them at all: the appearance of the face, disposition of the body would really make you think of village dwellers of the Axalcixe district; their language however was almost Mingrelian. When I announced my doubt about this, he brought out a copy of the 'vephis tqaosani,' from which he read aloud to me the following:

Their name is called Kaji, because they are banded together,

Men skilled in sorcery, exceeding cunning in the art,

Harmers of all men, themselves unable to be harmed by any; 
They that go out to join battle with them come back blinded and shamed.

[Wardrop translation, stanza 1225]

-Who knows that exactly about these people it was said? I asked.

-First wait, from below let me read to you:

For this reason all those that dwell roundabout call them Kajis,

Though they, too, are fleshly men like us.

[Wardrop translation 1226] ${ }^{38}$

In folklore, the kaji is a social being, living in a "society of nature" that at each step is parallel to the society of humans. Here, on the authority of Rustaveli, the kaji moves a further step from preternatural alterity to social alterity; the kaji is now a Mingrelian boy (as we saw before, in naturalistic debunking explanations of the kaji in a meadow in Racha, who, the author thought, was probably just a Mingrelian shepherd boy who did not know Georgian): "They are fleshly men like us." Fleshly like us, yes, but perhaps not quite exactly like us.

In contemporary Georgia, too, the figure of the kaji continues to serve as a figure of the ignorant rural folk (or especially, ex-rural urban folk) in relation to the educated intelligentsia (Manning 2009c). The primary contemporary meaning of kaji, outside of fairy-tale books in Georgia, is precisely in the meaning of "peasant, villager, lumpkin," with a particular sense something like a villager who is out of place who is in the city and wants to become a city dweller.

However, while it may seem there is no connection between the "fantastic" use of the term for a supernatural entity and the "slang" use for a natural one, beyond a simple metaphoric extension, we can see that the ways in which the fantastic was constitutive of the folk, that believing in kajis defined the universe of discourse of the folk in epistemic terms as being a discourse of the fantastic, as opposed to the real, could collapse into a more direct linguistic identification of the folk with the objects of their erstwhile belief. The elision of the folk into the fantastic allows the intelligentsia discourse of realism to remain in place, even as it moves from talking about the materially real, the natural, to valorizing mistaken folk beliefs as being nevertheless facts to be analyzed. But at the same time, it creates an unbridgeable epistemic divide between 
the writer and the written about (the folk and folk beliefs), almost as unbridgeable as the divide between the folk speaker and the fantastic objects spoken about. The folk come to be a bit more like kajis than chinkas; in that, like kajis and unlike chinkas, they can never really be domesticated. 